\title{
SISTEM INFORMASI PELAYANAN MASYARAKAT DI KELURAHAN PANARUNG, KECAMATAN PAHANDUT PALANGKARAYA BERBASIS WEB
}

\author{
Ade Chintia Desy ${ }^{a, 1, *}$, Enny Dwi Oktaviyani ${ }^{b, 2}$, Felicia Sylviana ${ }^{c, 3}$ \\ ${ }^{a}$ Universitas Palangka Raya, Jl. H. Timang \\ ${ }^{\mathrm{b}}$ Universitas Palangka Raya, Jl. H. Timang \\ ${ }^{\mathrm{c}}$ Universitas Palangka Raya, Jl. H. Timang \\ ${ }^{1}$ ade.c@mhs.it.upr.ac.id *; ${ }^{2}$ enny.obrien@gmail.com; ${ }^{3}$ felicia.upr@gmail.com \\ * corresponding author
}

\section{ARTICLE INFO}

\section{Keywords}

Information System

Panarung Village

Waterfall

PHP

MySQL

\begin{abstract}
Panarung village office, pahandut sub-district is one of the sub-districts located in the city of palangkaraya. In carrying out these tasks and functions, the Panarung village office does not yet have an information system that can support public service activities. All service processes are carried out manually. This study aims to create web based information system that can be used by outward employees in Panarung Village to carry out service activities to the people in the Panarung Village area using waterfall software development methods, PHP programming languages and MySQL databases. Testing using blackbox testing. Based on the test results, it can be concluded that this information system can be used for service activities to the community in the Panarung village
\end{abstract}

\section{Pendahuluan}

Kelurahan merupakan wilayah gabungan dari beberapa rukun warga (RW). Pemerintahan di tingkat desa dan kelurahan merupakan unsur pemerintahan yang berhubungan langsung dengan masyarakat. Dalam menjalankan semua perencanaan pembangunan di kelurahan terdapat Dewan Kelurahan (Dekel). Dewan Kelurahan berfungsi sebagai pemberi masukan kepada lurah tentang rencana pembangunan di wilayahnya. Dalam konteks otonomi daerah di Indonesia, kelurahan merupakan wilayah kerja yang dipimpin oleh Lurah dan berstatus sebagai Pegawai Negeri Sipil sebagai Perangkat Daerah Kabupaten atau kota. Kelurahan merupakan unit pemerintahan terkecil setingkat dengan desa, tetapi kelurahan memiliki hak mengatur wilayah yang lebih terbatas daripada desa dan dalam perkembangannya, sebuah desa dapat diubah statusnya menjadi kelurahan [1][2][3].

Kantor kelurahan panarung kecamatan pahandut merupakan salah satu kelurahan yang terletak di kota palangkaraya. Kelurahan panarung memiliki tugas dan fungsi untuk melaksanakan kewenangan pemerintahan yang dilimpahkan oleh camat serta melakukan tugas pemerintahan lainnya sesuai ketentuan. Kantor kelurahan panarung kecamatan pahandut memiliki fungsi salah satunya sebagai pemerintahan, keamanan dan ketertiban yang bertugas untuk membuat surat pernyataan penguasaan tanah, surat keterangan tanah, ahli waris, surat keterangan kematian, keterangan pindah dan pada pelayanan pengaduan. Dalam meaksanakan tugas dan fungsinya tersebut, kantor kelurahan panarung belum mempunyai sistem informasi yang dapat menunjang kegiatan pelayanan terhadap masyarakat. Semua proses pelayanan dilakukan secara manual.

Beberapa penelitian sebelumnya yang terkait penelitian ini adalah penelitian yang dilakukan oleh [4][6][7][8][9]. Penelitian [4] membangun sebuah sistem aplikasi kependudukan, dimana sistem dapat digunakan untuk mencatat data kependudukan dan mencangkup hal-hal yang 
berkaitan dengan data kependudukan tersebut seperti pencatatan biodata Penduduk, kematian, perpindahan Penduduk dan lain - lain. Sistem aplikasi kependudukan ini dibuat dengan memanfaatkan teknologi replikasi yang ada pada database mysql untuk membuat sistem database terdistribusi, dan untuk mempermudah pengaksesan sistem aplikasi kependudukan ini akan dibuat berbasis web. Penelitian ini bertujuan untuk membuat sebuah sistem informasi yang dapat digunakan oleh pegawai keluarahan di Kelurahan Panarung untuk melaksanakan kegiatan pelayanan kepada masyarakat yang berada di wilayah Kelurahan Panarung menggunakan bahasa pemrograman $P H P$ dan database MySQL. Sistem informasi yang di buat adalah sistem informasi pelayanan masyarakat bidang pemerintahan, keamanan dan ketertiban, yang meliputi surat pernyataan penguasaan tanah (SPPT), surat keterangan tanah, surat keterangan kematian, surat keterangan ahli waris, layanan pengaduan, indeks kepuasan pelayanan.

\section{Metodologi Penelitian}

Metodologi penelitian yang digunakan pada penelitian ini adalah :

a. Metode Pengamatan (Observasi)

Metode pengamatan (Observasi) adalah metode pengumpulan data dengan cara pengamatan langsung keobjek penelitian (Kelurahan Panarung Kecamatan Pahandut) guna memperoleh data atau gambaran serta keterangan terhadap sistem yang sudah berjalan.

b. Metode Wawancara (Interview)

Metode wawancara (Interview) adalah metode pengumpulan data yang penulis gunakan dengan cara menanyakan langsung kepada pihak-pihak yang bersangkutan baik lurah (kepala kelurahan) maupun karyawan yang ada di Kelurahan Panarung Kecamatan Pahandut untuk memperoleh data dan keterangan yang dibutuhkan untuk membangun sebuah sistem.

c. Metode Kepustakaan

Metode kepustakaan adalah metode pengumpulan data dengan cara mempelajari buku-buku yang berhubungan dengan perancangan sistem informasi yang telah disediakan diperpustakaan.

d. Metode dokumentasi

Metode Dokumentasi adalah metode dengan cara mengumpulkan data pada Kelurahan Panarung Kecamatan Pahandut

e. Metode Eksperimen

Metode eksperimen adalah metode dengan cara melakukan percobaan terhadap program yang akan dibuat, untuk memperoleh hasil yang baik sesuai dengan yang dikehendaki

Metode pengembangan perangkat yang digunakan adalah metode waterfall yang meliputi proses sebagai berikut :

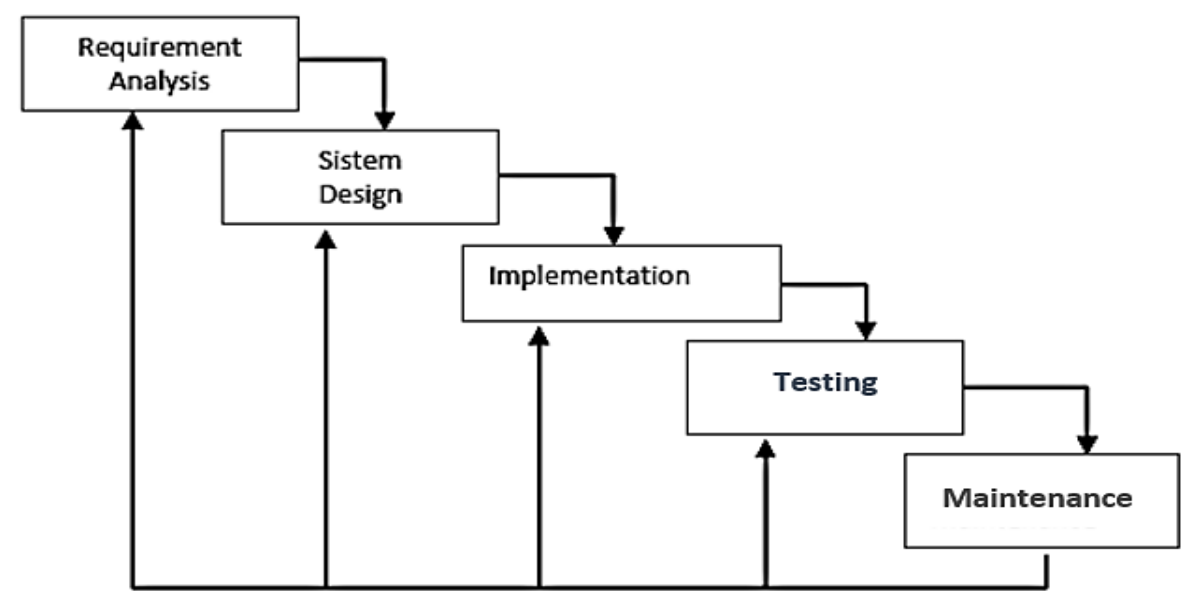

Gambar 1. Metode Pengembangan Perangkat Lunak Waterfall 
Berikut adalah penjelasan dari tahap-tahap yang dilakukan di dalam model ini.

a. Requirement analysis

Requirement analysis adalah menganalisis kebutuhan yang diperlukan oleh pihak warga dan kelurahan panarung kecamatan pahandut dalam perancangan website sistem informasi pelayanan masyarakat bidang pemerintahan, keamanan dan ketertiban pada kelurahan panarung, kecamatan pahandut palangkaraya berbasis web. Dalam tahap ini juga dilakukan beberapa analisi diantaranya :

1) Analisa Pengguna

2) Analisis sistem lama

3) Analisa alur diagram (flowchart) sistem lama

4) Evaluasi permasalahan

5) Alat dan bahan

b. Sistem dan desaign (Perancangan Sistem)

Sistem dan desaign merupakan pendesainan sistem yang akan dibuat setelah mengumpulkan kebutuhan yang sudah diperlukan. Pada tahap ini mengimplementasikan kebutuhan yang telah disebutkan pada tahap sebelumnya.

Perancangan yang akan dilakukan adalah sebagai berikut.

1) Perancangan DFD (data flow diagram) sistem

2) Perancangan Basis Data

a) Perancangan ERD (entity relationship diagram)

b) Perancangan Tabel

3) Perancangan Antarmuka

a) Struktur navigasi

b) Storyboard

4) Perancangan CMS (content management system)

c. Implementation (Penulisan Program)

Perancangan perangkat lunak direalisasikan sebagai serangkaian program atau unit program. Pengujian unit melibatkan verifikasi bahwa setiap unit telah memenuhi spesifikasinya. Untuk dapat dimengerti oleh mesin atau komputer, maka desain tadi harus diubah bentuknya menjadi bentuk yang dapat dimengerti oleh mesin, yaitu kedalam bahasa pemrograman melalui proses coding. Tahap ini merupakan implementasi dari tahap desain yang secara teknis nantinya dikerjakan, Bahasa pemrograman yang digunakan adalah PHP, javascript, dan HTML [5].

d. Testing (Pengujian)

Setelah pembuatan desain interface, dan dilakukan pembangunan program, Website yang telah dibuat akan diimplementasikan. Website yang dibuat akan diberlakukan proses percobaan terlebih dahulu, jika ada kesalahan, maka akan kembali ke metodologi sebelumnya.

Setelah kode program selesai, dan program dapat berjalan, testing dapat dimulai, testing difokuskan pada logika internal dari perangkat lunak, fungsi eksternal, dan mencari segala kemungkinan kesalahan, memeriksa apakah sesuai dengan hasil yang diinginkan. Tahap testing menggunakan blackbox testing.

1) Blackbox Testing

Pengujian perancangan dilakukan sejak awal proses pengembangan system, biasanya testing dilakukan oleh user. Penjelasan pengujian blackbox:

a) Digunakan untuk menguji fungsi-fungsi khusus dari perangkat lunak yang dirancang.

b) Kebenaran perangkat lunak yang diuji hanya dilihat berdasarkan keluaran yang dihasilkan dari data masukan yang diberikan untuk fungsi yang ada tanpa melihat bagaimana proses untuk mendapatkan keluaran tersebut. 
c) Dari keluaran yang dihasilkan, kemampuan program dalam memenuhi kebutuhan pemakai dapat diukur sekaligus dapat diketahui kesalahan-kesalahannya.

2) Pengujian menggunakan browser

Pengujian aplikasi web terhadap beberapa browser bertujuan untuk mengetahui apakah website yang dibuat mampu berjalan sempurna pada semua browser. Browser yang digunakan untuk pengujian adalah Mozilla Firefox, Internet Explorer dan Google Chrome.

e. Maintenance (Pemeliharaan)

Tahap ini adalah tahap pemeliharaan sistem.

\section{Hasil dan Pembahasan}

Pengguna pada sistem informasi kelurahan panarung kecamatan pahandut palangkaraya ini ada 3 pengguna, yaitu admin bidang, warga dan lurah.

1. Admin bidang

Admin bidang adalah pengguna yang dapat mengelola website, seperti mengelola data admin bidang, kelola data warga, kelola data lurah, mengelola edit data profil, surat masuk mengelola data master surat penyataan penguasaan tanah, mengelola data master surat keterangan tanah, mengelola data master surat keterangan kematian, mengelola data master surat keterangan ahli waris, surat selesai mengelola data master surat penyataan penguasaan tanah, mengelola data master surat keterangan tanah, mengelola data master surat keterangan kematian, mengelola data master surat keterangan ahli waris, mengelola data pengaduan, data indek kepuasan, mengelola laporan surat.

2. Warga

Warga adalah pengguna sistem yang dapat melihat persyaratan permohonan, mengelola edit data profil mengelola data penyataan penguasaan tanah, mengelola data surat keterangan tanah, mengelola data surat keterangan kematian, mengelola data surat keterangan ahli waris, mengelola data aduan, mengelola survei kepuasan.

3. Lurah

Lurah adalah pengguna yang hanya dapat mengelola edit profil dan melihat informasi pada website mengelola data surat penyataan penguasaan tanah, mengelola data surat keterangan tanah, mengelola data surat keterangan kematian, mengelola data surat keterangan ahli waris, mengelola data indek kepuasan, laporan data surat penyataan penguasaan tanah, laporan data master surat keterangan tanah, laporan data surat keterangan kematian, laporan data surat keterangan ahli waris.

Sistem informasi pengolahan data kepegawaian berbasis web ini menggunakan Data Flow Diagram (DFD), dimana tingkatan dalam desain sistem yang pertama adalah diagram konteks yang akan menggambarkan lingkup alur kegiatan dari seluruh pengguna sistem dipresentasikan dengan lingkaran tunggal yang akan mewakili keseluruhan sistem, kemudian diikuti dengan diagram level zero atau diagram nol yang merupakan dekomposisi dari diagram konteks. Diagram konteks ditunjukkan pada gambar 2, dan diagram level 1 ditunjukkan pada gambar 3 


\section{Jukn reeminn}

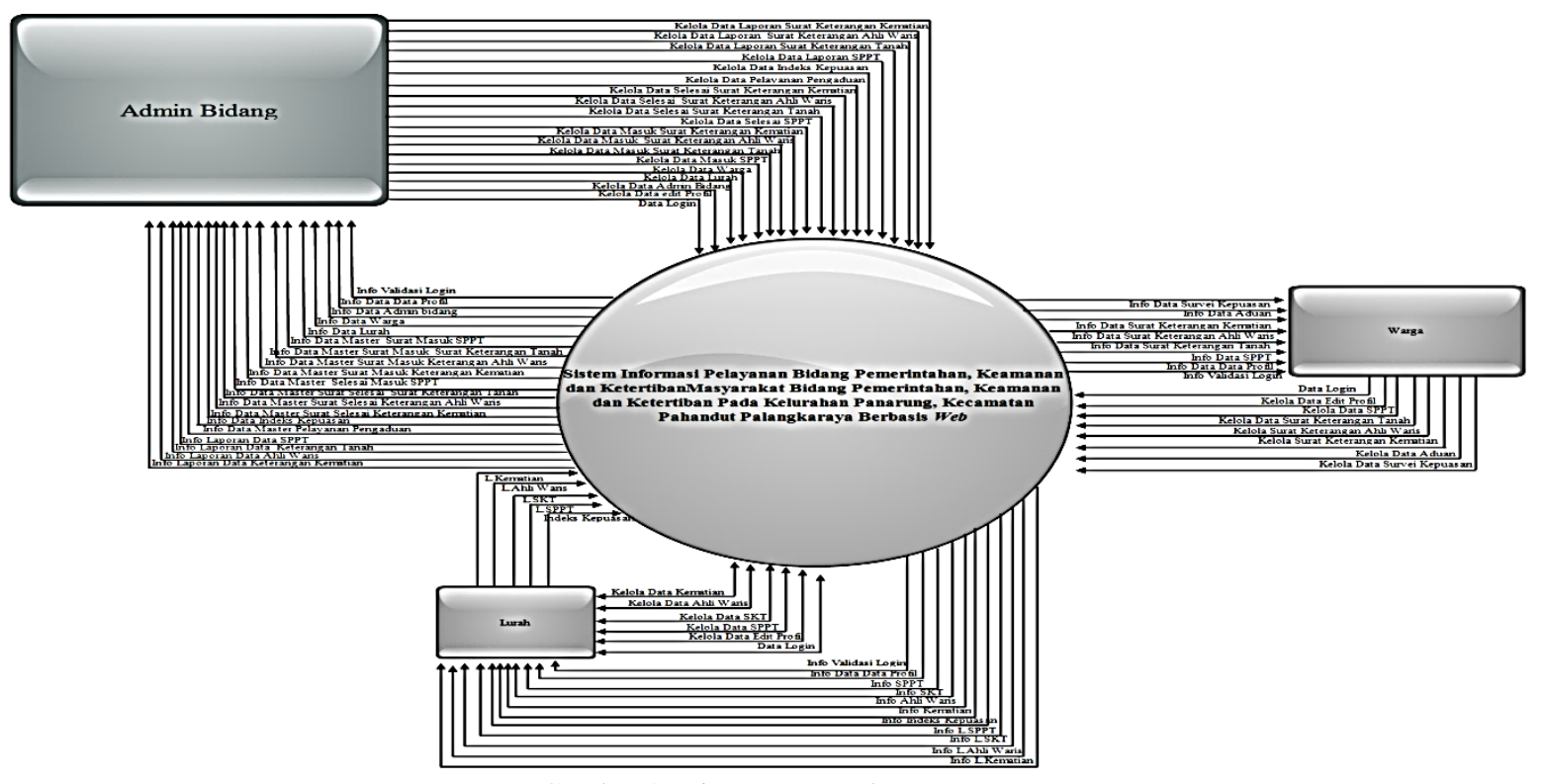

Gambar 2. Diagram Konteks 


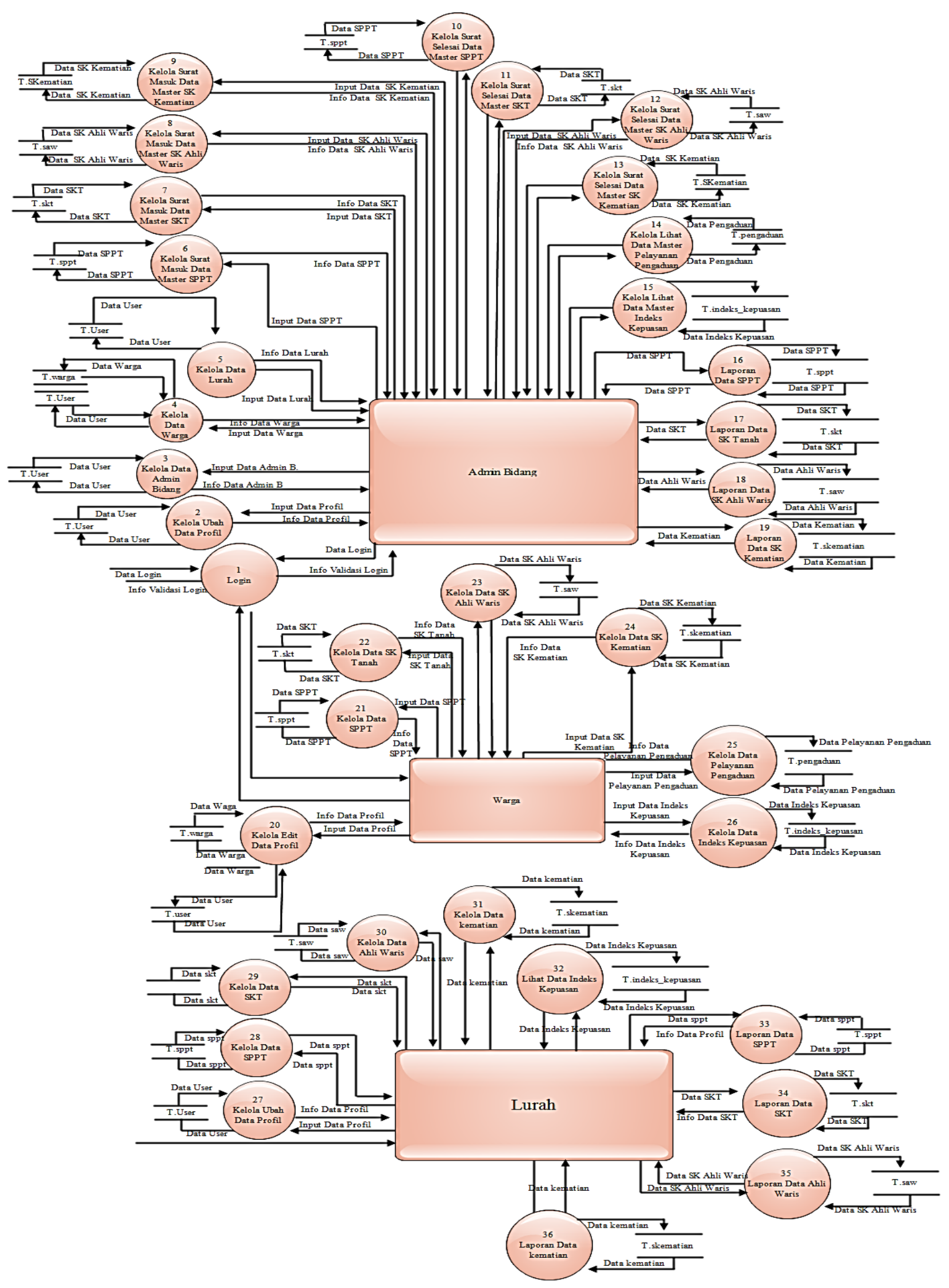

Gambar 3. DFD Level 1 
Jitis

Entity Relationship Diagram (ERD) digunakan untuk menggambarkan relasi atau keterkaitan antar tabel-tabel pada penelitian ini. ERD pada penelitian ini ditunjukkan pada gambar 4.

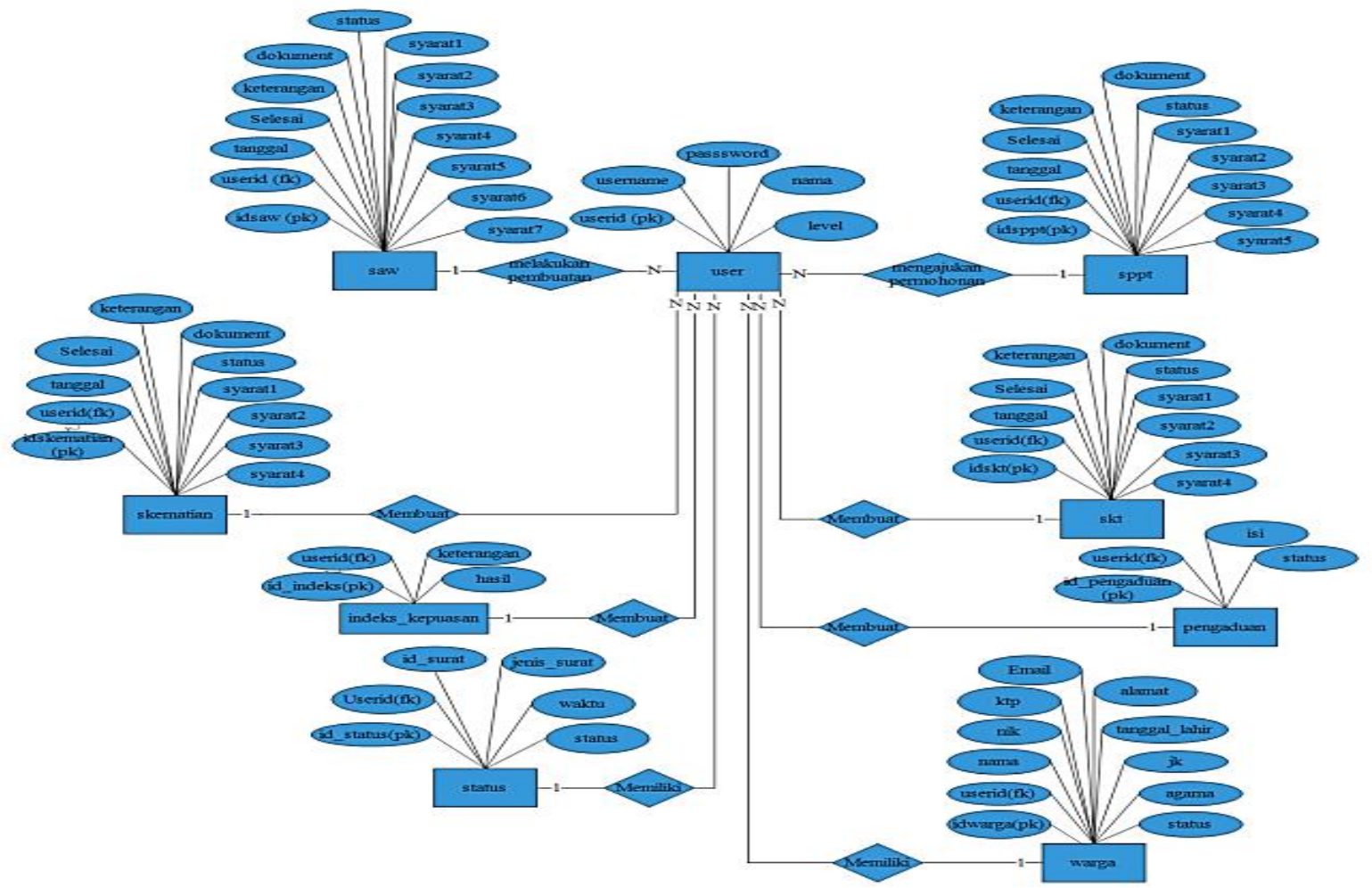

Gambar 4. Entity Relationship Diagram (ERD)

Desain dari basis data yang digunakan untuk pembuatan sistem informasi pelayanan umum bidang pemerintahan keamanan dan ketertiban kelurahan panarung kecamatan pahandut berbasis web yang dibuat dengan menggunakan MySQL. Basis data dibuat dengan nama kelurahan. Tabel yang ada pada database kelurahan yakni tabel user, tabel warga, table status, tabel sppt, tabel skt, tabel skematian, tabel saw, tabel pengaduan, tabel indeks_kepuasan.

Rancangan database yang digunakan dalam sistem informasi pelayanan umum bidang pemerintahan keamanan dan ketertiban kelurahan panarung kecamatan pahandut berbasis web ini terdiri dari beberapa tabel yang berfungsi sebagai media penyimpanan data. Tabel yang digunakan dalam penelitian ini berjumlah 9 (sembilan) buah tabel, yaitu :

1. Nama tabel

Fungsi tabel
: Data User

: Memasukkan Data user

Tabel 1 Struktur Tabel Data user

\begin{tabular}{|c|l|c|c|}
\hline No. & \multicolumn{1}{|c|}{ Nama Field } & Type Data & Panjang \\
\hline 1. & userid (primary key) & int & 11 \\
\hline 2. & Username & Varchar & 50 \\
\hline 3. & Password & Varchar & 50 \\
\hline 4. & Nama & Varchar & 50 \\
\hline 6. & Level & Varchar & 50 \\
\hline
\end{tabular}

2. Nama Tabel

Fungsi Tabel
: Data warga

: Memasukkan data warga 
Tabel 2 Struktur Tabel Data Warga

\begin{tabular}{||c|l|c|c|}
\hline No. & \multicolumn{1}{|c|}{ Nama Field } & Type & Panjang \\
\hline 1. & Idwarga & Int & 11 \\
\hline 2. & Userid & Int & 11 \\
\hline 3. & Nama & Varchar & 50 \\
\hline 4. & Nik & Varchar & 50 \\
\hline 5. & Ktp & Varchar & 50 \\
\hline 6. & Email & Varchar & 50 \\
\hline 7. & Alamat & Varchar & 50 \\
\hline 8. & Tanggal_lahir & Varchar & 50 \\
\hline 9. & Jk & Varchar & 50 \\
\hline 10. & Agama & Varchar & 50 \\
\hline 11. & status & Int & 11 \\
\hline
\end{tabular}

3. Nama Tabel

Fungsi Tabel
: Data Status

: Memasukkan Data Status

Tabel 3 Struktur Tabel Data Status

\begin{tabular}{|c|l|c|c|}
\hline No. & \multicolumn{1}{|c|}{ Nama Field } & Type Data & Panjang \\
\hline 1. & id_status & int & 11 \\
\hline 2. & userid & int & 11 \\
\hline 3. & id_surat & int & 11 \\
\hline 4. & jenis_surat & Varchar & 20 \\
\hline 5. & waktu & Varchar & 50 \\
\hline 6. & status & Varchar & 50 \\
\hline
\end{tabular}

4. Nama Tabel

Fungsi Tabel
: Data SPPT

: Memasukkan Data Jabatan

Tabel 4 Struktur Tabel Data SPPT

\begin{tabular}{||c|l|c|c|}
\hline No. & Nama Field & Type & \\
\hline 1. & Idsppt & Int & 11 \\
\hline 2. & userid & Int & 11 \\
\hline 3. & Tanggal & Varchar & 50 \\
\hline 4. & Selesai & Varchar & 50 \\
\hline 5. & Keterangan & Varchar & 50 \\
\hline 6. & Document & Varchar & 50 \\
\hline 7. & Status & Varchar & 50 \\
\hline 8. & Syarat1 & Varchar & 50 \\
\hline 9. & Syarat2 & Varchar & 50 \\
\hline 10. & Syarat3 & Varchar & 50 \\
\hline 11. & Syarat4 & Varchar & 50 \\
\hline 12. & Syarat5 & Varchar & 50 \\
\hline
\end{tabular}

5. Nama Tabel

Fungsi Tabel
: SKT

: Memasukkan Data SKT

Tabel 5 Struktur Tabel SKT

\begin{tabular}{||c|l|c|c|}
\hline No. & Nama Field & Type & \\
\hline 1. & Idskt & Int & 11 \\
\hline 2. & userid & Int & 11 \\
\hline 3. & Tanggal & Varchar & 50 \\
\hline 4. & Selesai & Varchar & 50 \\
\hline 5. & Keterangan & Varchar & 50 \\
\hline 6. & Document & Varchar & 50 \\
\hline 7. & Status & Varchar & 50 \\
\hline 8. & Syarat1 & Varchar & 50 \\
\hline
\end{tabular}




\begin{tabular}{||c|l|l|l|}
\hline 9. & Syarat2 & Varchar & 50 \\
\hline 10. & Syarat3 & Varchar & 50 \\
\hline 11. & Syarat4 & Varchar & 50 \\
\hline
\end{tabular}

6. Nama Tabel Fungsi Tabel
: Data Saw

: Memasukkan Data Saw

Tabel 6 Struktur Tabel Data Saw

\begin{tabular}{||c|l|c|c|}
\hline \hline No. & Nama Field & Type & \\
\hline 1. & Idsaw & Int & 11 \\
2. & userid & Int & 11 \\
\hline 3. & Tanggal & Varchar & 50 \\
\hline 4. & Selesai & Varchar & 50 \\
\hline 5. & Keterangan & Varchar & 50 \\
\hline 6. & Document & Varchar & 50 \\
\hline 7. & Status & Varchar & 50 \\
\hline 8. & Syarat1 & Varchar & 50 \\
\hline 9. & Syarat2 & Varchar & 50 \\
\hline 10. & Syarat3 & Varchar & 50 \\
\hline 11. & Syarat4 & Varchar & 50 \\
\hline 12. & Syarat5 & Varchar & 50 \\
\hline 13. & Syarat6 & Varchar & 50 \\
\hline 14. & Syarat7 & Varchar & 50 \\
\hline
\end{tabular}

7. Nama Tabel Fungsi Tabel
: Data Skematian

: Memasukkan Data Skematian

Tabel 7 Struktur Tabel Skematian

\begin{tabular}{||c|l|c|c|}
\hline \hline No. & Nama Field & Type & \\
\hline 1. & Idskematian & Int & 11 \\
\hline 2. & userid & Int & 11 \\
\hline 3. & Tanggal & Varchar & 50 \\
\hline 4. & Selesai & Varchar & 50 \\
\hline 5. & Keterangan & Varchar & 50 \\
\hline 6. & Document & Varchar & 50 \\
\hline 7. & Status & Varchar & 50 \\
\hline 8. & Syarat1 & Varchar & 50 \\
\hline 9. & Syarat2 & Varchar & 50 \\
\hline 10. & Syarat3 & Varchar & 50 \\
\hline 11. & Syarat4 & Varchar & 50 \\
\hline
\end{tabular}

8. Nama Tabel Fungsi Tabel
: Data Pengaduan

: Memasukkan Data Pengaduan

Tabel 8 Struktur Tabel Data Pengaduan

\begin{tabular}{||c|l|c|c|}
\hline \hline No. & \multicolumn{1}{|c|}{ Nama Field } & Type & Panjang \\
\hline 1. & Id_Pengaduan & Int & 11 \\
\hline 2. & userid & int & 11 \\
\hline 3. & isi & text & \\
\hline 4. & status & Varchar & 20 \\
\hline
\end{tabular}


Jin

9. Nama Tabel

Fungsi Tabel
: Data Indeks_Kepuasan

: Memasukkan Data Indeks_Kepuasan

Tabel 9 Struktur Tabel Data Indeks_Kepuasan

\begin{tabular}{|c|l|l|l|}
\hline No. & Nama Field & Type & Panjang \\
\hline 1. & Id_indeks & int & 11 \\
\hline 2. & Keterangan & Varchar & 20 \\
\hline 3. & Hasil & Int & 11 \\
\hline
\end{tabular}

Hasil dari penelitian ini adalah sistem informasi berbasis web untuk Kelurahan Panarung. Gambar 5 menunjukkan halaman login yang digunakan untuk validasi admin bidang, warga dan lurah untuk dapat masuk ke halaman selanjutnya

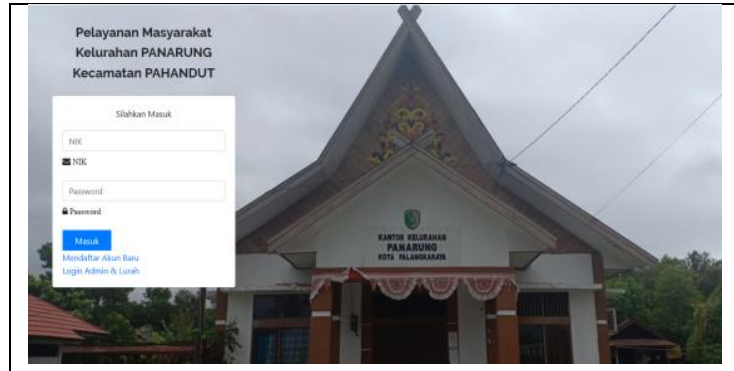

Gambar 5. Halaman login admin bidang, warga, dan lurah

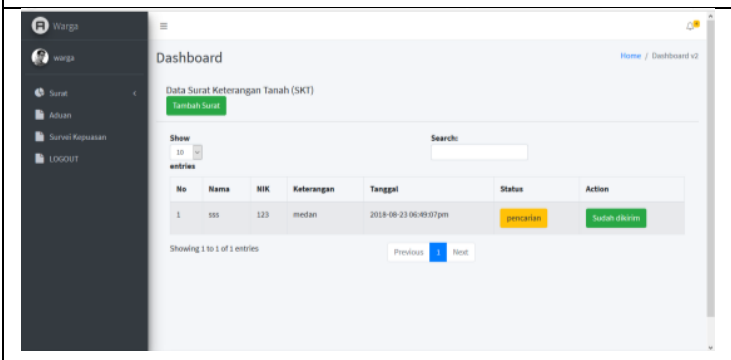

Gambar 7. halaman kelola data Surat Keterangan Tanah

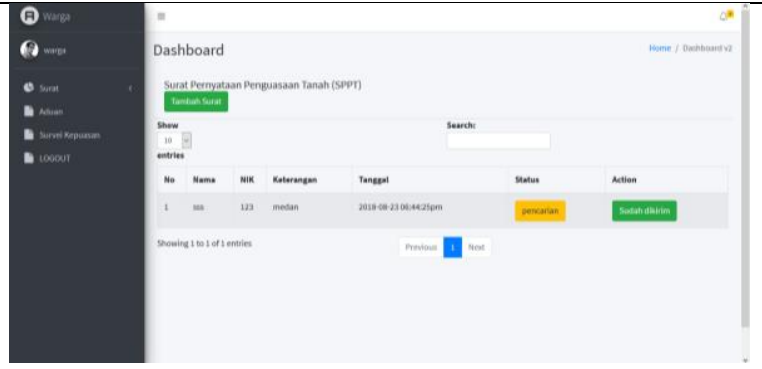

Gambar 6. Halaman kelola surat pernyataan penguasaan tanah

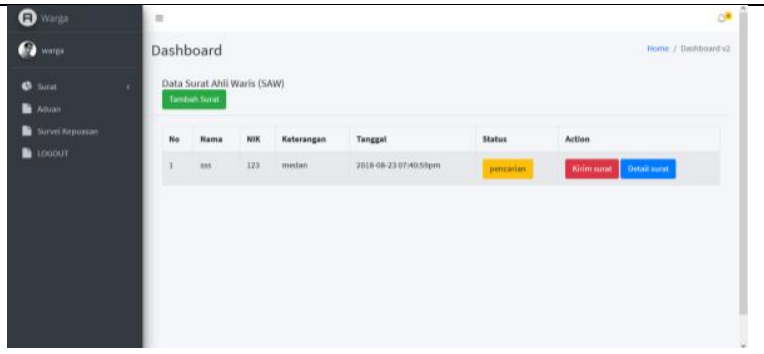

Gambar 8. Halaman kelola data Surat Keterangan Ahli Waris

Gambar 6 menunjukkan halaman kelola surat pernyataan penguasaan tanah yang akan di inputkan oleh warga yang digunakan untuk warga menginputkan data surat pernyataan penguasaan tanah yang akan dikirimkan ke admin bidang

Gambar 7 menunjukkan halaman kelola surat keterangan tanah yang akan di inputkan oleh warga yang digunakan untuk warga menginputkan data surat keterangan tanah yang akan dikirimkan ke admin bidang

Gambar 8 merupakan halaman kelola surat keterangan ahli waris yang akan di inputkan oleh warga yang digunakan untuk warga menginputkan data surat keterangan ahli waris yang akan dikirimkan ke admin bidang 

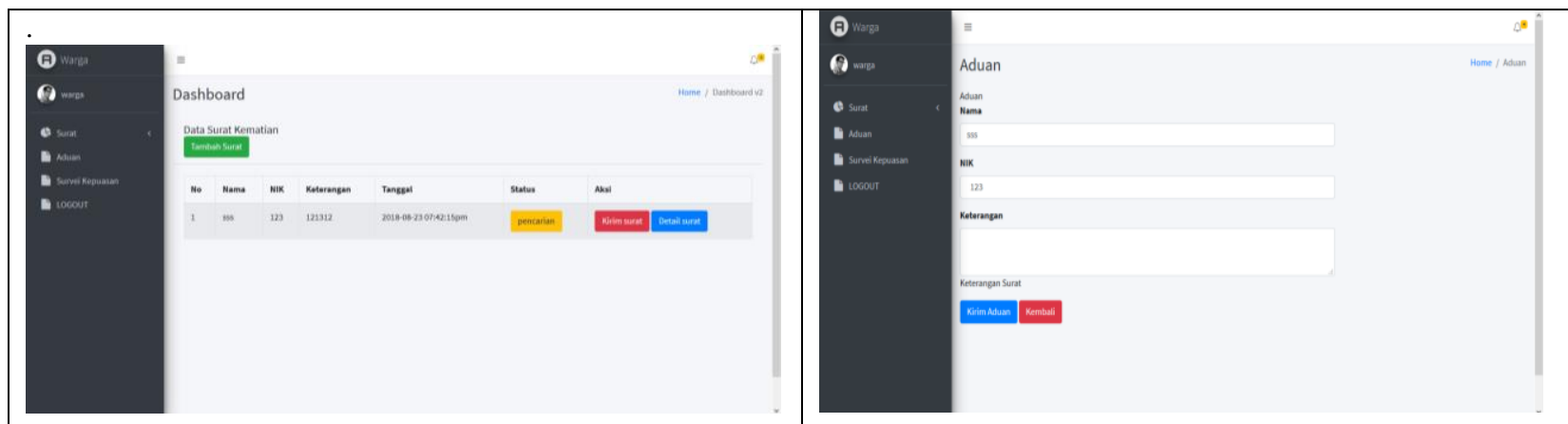

Gambar 9. halaman kelola data Surat Keterangan Kematian

Gambar 10. Halaman kelola data Pengaduan

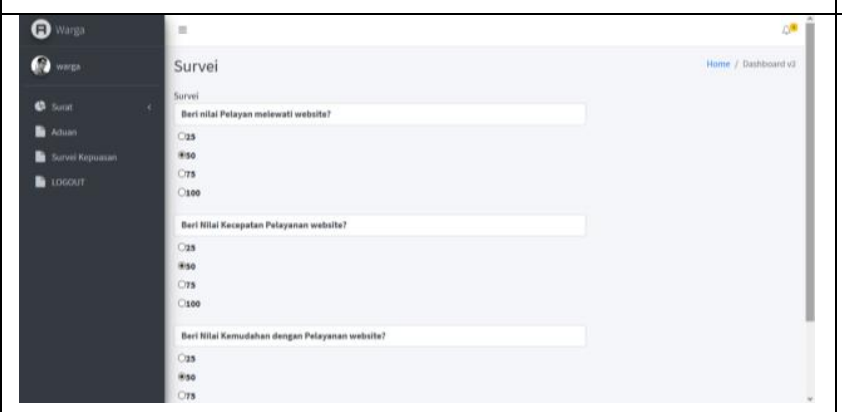

Gambar 11. halaman kelola data Survei Indeks Kepuasan

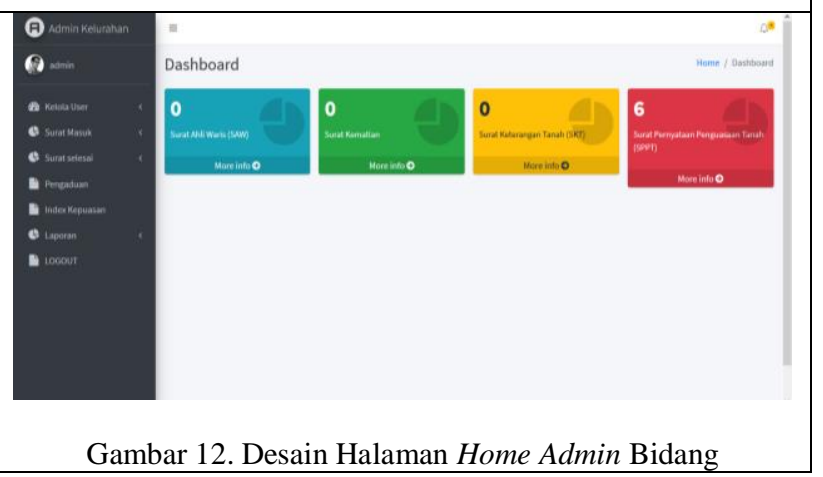

Gambar 9 merupakan halaman kelola surat keterangan kematian yang akan di inputkan oleh warga yang digunakan untuk warga menginputkan data surat keterangan kematian yang akan dikirimkan ke admin bidang

Gambar 10 diatas merupakan halaman kelola pengaduan yang akan di inputkan oleh warga yang digunakan untuk warga menginputkan data pengaduan yang akan dikirimkan ke admin bidang.

Gambar 11 diatas merupakan halaman kelola survei indeks kepuasan yang akan di inputkan oleh warga yang digunakan untuk warga menginputkan data survei indeks kepuasan yang akan dikirimkan ke admin bidang.

Gambar 12 diatas merupakan rancangan halaman home admin bidang yang digunakan untuk admin bidang mengelola data, mengedit dan menginputkan data.

\section{Kesimpulan}

Kesimpulan dari penelitian ini adalah :

a. Dengan adanya Sistem Informasi ini, penduduk dapat memperoleh informasi mengenai proses pembuatan surat dan agenda kegiatan kelurahan.

b. Meminimalisir kehilangan berkas arsip surat dan ketidak konsistenan data penduduk yang berada di RT dengan kelurahan.

c. Sistem ini dapat membantu kelurahan dalam mendapatkan laporan surat, serta laporan kuesioner dan mengurangin biaya transportasi yang di tanggung oleh penduduk.

d. Membantu lurah dalam mengambil keputusan dalam menentukan tingkat kepuasan penduduk terhadap kelurahan dalam pelayanan public

\section{Ucapan Terima Kasih}

Kami berterimakasih kepada Jurusan Teknik Informatika, Unversitas Palangka Raya dan rekan-rekan sejawat yang telah mendukung penelitian kami 


\section{Daftar Pustaka}

[1] Kota Palangkaraya. Peraturan Walikota Palangkaraya Nomor 51 Tahun 2016 tentang Uraian Tugas dan Fungsi Jabatan Struktural Sekretariat Daerah Kota Palangkaraya pada Kelurahan Kota Palangkaraya.

[2] Kota Palangkaraya. Peraturan Daerah Kota Palangkaraya Nomor 01 Tahun 2009 tentang Organisasi Dan Tata Kerja Kecamatan Dan Kelurahan di Kota Palangkaraya.

[3] Kota Palangkaraya. Peraturan Daerah Kota Palangkaraya Nomor 4 Tahun 2016 tentang Penyelenggaraan Administrasi Kependudukan.

[4] M. Kamisutara, "Sistem Informasi Administrasi Kependudukan Di Kelurahan Jajar Tunggal Kec. Wiyung Surabaya Dengan Menggunakan Model Proses Waterfall”, Fakultas Teknik-Itats, 2013

[5] Nugroho, Bunafit, "Latihan Membuat Aplikasi Web Php Dan Mysql Dengan Dreamweaver Mx (6, 7, 2004) Dan 8", Yogyakarta : Gava Media, 2008

[6] Rahmawati, Tika,. "Pembangunan Sistem Informasi Administrasi Kelurahan Kedungwaduk, Kecamatan Karangmalang, Kabupaten Sragen”, Fakultas Teknologi Informatika Universitas Surakarta, 2013

[7] R. Dwi, Vintya, "Kualitas Pelayanan Administrasi Terpadu Kecamatan Di Kantor Kecamatan Gondokusuman Yogyakarta", 2015

[8] Supriyannto, "Sistem Informasi Administrasi Data Kependudukan Pada Kantor Kelurahan Desa Demangan Kabupatenn Boyolali”, Program Studi: Sistem Informasi S1 Fakultas Ilmu Komputer Universitas Dian Nuswantoro Semarang, 2015

[9] S. Hidayatulloh, C. Mulyadi, "Sistem Pelayanan Administrasi Kependudukan Desa Candigatak Berbasis Web". Junal IT Cida No.1 1 Desember 2015 